\title{
Correction to: Ultrasonographic features of acute Charcot neuroarthropathy of the foot: a pilot study
}

\author{
M. Mortada ${ }^{1}$ - N. Ezzeldin ${ }^{1} \cdot$ Marwa Hammad $^{1}$ (D) \\ Published online: 13 October 2020 \\ (C) International League of Associations for Rheumatology (ILAR) 2020
}

\section{Correction to: Clinical Rheumatology https://doi.org/10.1007/s10067-020-05107-2}

The authors of the original version of the above article requested the below corrections to be noted. [Bold text used to highlight problem area]

\section{Patients and methods}

This is an observational study where 26 patients with $\mathrm{CN}$ of the foot between January 2013 and December 2018 were enrolled. Inclusion criteria were: (1) foot pain and swelling, (2) MRI Short-TI Inversion Recovery (STIR) findings of acute $\mathrm{CN}$ based on a radiologist opinion; subchondral bone marrow edema, soft tissue edema, and joint effusion with or without subchondralmicrofractures (grade 0 on Modified Eichenholtz classification system), [17, 18] presented in Table 1. Patients with other forms of arthropathy that may mimic acute $\mathrm{CN}$, e.g., gouty arthritis and rheumatoid arthritis, were excluded from the study. This study was approved by the institutional review board of our university (Zagazig University Institutional Review Board), and an informed consent was taken from all patients.

The online version of the original article can be found at https://doi.org/ $10.1007 /$ s $10067-020-05107-2$

Marwa Hammad

marwahany22@hotmail.com

M. Mortada

m_a_mortada@yahoo.com

N. Ezzeldin

nillie_ezz@yahoo.com

1 Rheumatology \& Rehabilitation Department, Faculty of Medicine, Zagazig University, Zagazig, Egypt

\section{Ultrasonographic examination}

Ultrasonographic examination of mid-tarsal and ankle joints was performed with a 5-12 MHz linear probe, Medison SonoAce R3.The method of US examination was according to the guidelines published by Backhaus et al. [19]. Synovitis was defined according to the published OMERACT definitions [20].Synovitis on gray-scale US was evaluated using a semiquantitative 4 -grade scale of $0-3$, as presented in Table2.Ultrasound-detected bony erosions were defined according to OMERACT definition as an intra-articular discontinuity of the bone surface that is visible in two perpendicular planes. Bone erosions at mid-tarsal joints were not included due to the normal irregular surface of tarsal bones, which is liable to high degree of misinterpretations.

\section{Figure 1 (legend)}

Mid-tarsal joints (longitudinal scan), B-mode frequency 12 MHz. a. Effusion and synovitis at mid-tarsal joints in a case of Charcot foot arthropathy. b Grade 3 Doppler activity at mid-tarsal joint in a case of Charcot foot arthropathy

\section{Figure 2 (legend)}

Ankle joint (anterior longitudinal scan), B-mode frequency 12 MHz. a Grade 2 Doppler activity with effusion and synovitis of ankle joint associated with minor erosions of tibia in a case of Charcot joint. $b$ Effusion at ankle joint in a case of Charcot joint.

\section{References}

17. Eichenholtz SN (1996) Charcot joints. Charles C. Thomas, Springfield

18. Shibata T, Tada K, Hashizume C (1990) The results of arthrodesis of the ankle for leprotic neuroarthropathy. $\mathrm{J}$ bone Joint Surg Am 72:749-756 Charcot arthropathy in ultrasound examination - a case report 
19. Backhaus M, Burmester G, Gerber T, Grassi W, Machold K, Swen WA, Wakefield RJ, Manger B, Working Group for Musculoskeletal Ultrasound in the EULAR Standing Committee on International Clinical Studies including Therapeutic Trials (2001) Guidelines for musculoskeletal ultrasound in rheumatology. Ann Rheum Dis 60:641-649

20. Wakefield R, Balint P, Szkudlarek M, Filippucci E, Backhaus M, D'Agostino MA, Sanchez EN, Iagnocco A, Schmidt WA, Bruyn GA, Kane D, O'Connor PJ, Manger B, Joshua F, Koski J, Grassi W, Lassere MN, Swen N,
Kainberger F, Klauser A, Ostergaard M, Brown AK, Machold KP, Conaghan PG, OMERACT 7 Special Interest Group (2005) Musculoskeletal ultrasound including definitions for ultrasonographic pathology. J Rheumatol 32(12):2485- 2487

Publisher's note Springer Nature remains neutral with regard to jurisdictional claims in published maps and institutional affiliations. 